\title{
From usability requirement to technical specifications for hand-held tools and materials: an applied research in the construction field
}

\author{
Gabriella Duca ${ }^{\mathrm{a},}{ }^{*}$ and Erminia Attaianese ${ }^{\mathrm{a}}$ \\ ${ }^{a}$ Department DICATA/LEAS Laboratory, University of Naples Federico II, Via Tarsia 31, 80135, Naples, Italy
}

\begin{abstract}
Literature shows incidence of musculoskeletal disorders in bricklaying workers as well as the relevance of good designed hand-held tools in musculoskeletal disorders prevention. In this framework, it can be supposed that providing usable hand-held tools and material in construction worksites will help to improve bricklayers' working conditions. Here a study is presented aimed at framing a methodology for usability assessment of bricklayers handled objects, in order to provide employers with practical indicators for choosing tools and materials best fitting workers needs, under the effectiveness, efficiency and satisfaction perspective. On the basis of a task analysis, usability requirements for bricklaying hand-held tools and materials have been detailed and related, quantitative and qualitative, technical specifications have been elicited. Theoretical framework and usability assessment methodology are presented and, finally, findings from a field application are discussed.
\end{abstract}

Keywords: bricklayers; ergonomic assessment; task analysis, workers, performances

\section{Introduction}

It is well known the existence of a strong relationship between occurrence of musculoskeletal disorders and excessive use of poorly designed hand tools [1]. Even if many studies have been carried out about assessment of the ergonomic quality of hand-held tools, only a limited number of usability aspects have been investigated [2] [3] [4] and generally focusing on a single tool type [5] [6] [7] [8]. On the other hand EU regulations request employers to provide workers with equipments and materials chosen to minimize every possible physical constraint during their use [9] They have to permit operators to execute their job reducing effort demand, avoiding long and useless actions and then reducing human errors, in order to assure comfort and wellbeing on work.

To cover the gap between regulations requests and applied studies, the presented research was founded by Laboratory of Applied and Experimental Ergo- nomics (LEAS ${ }^{i}$ ) of University of Naples Federico II and Salerno district "Bilateral organization of construction companies and workers trade union" (CPT). Main aim of the research was the identification of criteria for helping employers to select or purchase the best ergonomically designed construction materials [10] and powered and not powered hand-held tools.

\section{Applied methodology}

The study was focused on usability in constructions masonry activities, considering usability in a wide perspective that includes health and safety issues, together with hand-held tools and materials adequacy in terms of effectiveness, efficiency and operators' satisfaction [5] [2].

The study started with a detailed task analysis of masonry activities [12] [13], in three construction

\footnotetext{
${ }^{*}$ Corresponding author. E-mail: duca@unina.it.
} 
sites, in order to evidence main operators constraints when using analyzed tools and materials. From the task analysis, a set of factors affecting the usability performance of tools and materials used in bricklaying was evidenced, as listed hereafter:

- Physical demands

- Precision
- Times

- Quality controls

- Production of residues or foulness

- Safety risks.

Table 1

Categories of usability requirements and requirements elicitation for hand-held tools and materials in construction.

\begin{tabular}{|c|c|c|}
\hline REQUIREMENT CATEGORY & REQUIREMENT & $\begin{array}{l}\text { NUMBER OF RELATED TECHNICAL } \\
\text { SPECIFICATION }\end{array}$ \\
\hline \multirow[t]{3}{*}{ Comfortable use } & - Easy to handle & $\begin{array}{c}21 \\
\text { (with } 5 \text { sub-technical specifications) }\end{array}$ \\
\hline & Efficiency in use & 7 \\
\hline & Easy to transport & 5 \\
\hline \multirow[t]{4}{*}{ Maintainability } & Easy to clean & 4 \\
\hline & - Chemical agents proof & 1 \\
\hline & Water proof & 1 \\
\hline & - Easy to repair & 3 \\
\hline \multirow[t]{2}{*}{ Comprehensibility } & Self explanatory & $\begin{array}{c}16 \\
\text { (with } 8 \text { sub-technical specifications) }\end{array}$ \\
\hline & - Contextual information & $\begin{array}{c}3 \\
\text { (with } 3 \text { sub-technical specifications) }\end{array}$ \\
\hline \multirow[t]{6}{*}{ Injury protection } & Mechanical resistance & 3 \\
\hline & - Thermal shock proof & 2 \\
\hline & Electrocution proof & 5 \\
\hline & - Stable hold & 3 \\
\hline & - Accidental activation proof & 2 \\
\hline & - Minimum wastage & 2 \\
\hline \multirow[t]{5}{*}{ Health protection } & - Natural posture & $\begin{array}{c}11 \\
\text { (with } 4 \text { sub-technical specifications) }\end{array}$ \\
\hline & - Minimum physical effort & 13 \\
\hline & - Minimum vibration emission & 3 \\
\hline & - Minimum noise emission & 1 \\
\hline & Minimum wastage & 2 \\
\hline
\end{tabular}

From those inputs, five categories of ad-hoc usability requirements were formulated and, for each of them, a set of requirements was defined (as shown in Table 1). Finally technical specifications, with qualitative and -when possible- quantitative indicators, have been elicited.

In the elicitation process following aspects were detailed:

- tool/material intrinsic characteristics

- mechanical components of the physical effort (strength, torsion, acceleration)

- tool/material mass, centre and gravity

- dimensions of tool/material and its handler/grip area

- handle and grip area features
- effects of tool/material use on worker

- posture

- angles of wrist flexion/extension

- muscular effort and fatigue

- localized pressure areas on the hand

- possible accidents.

A total of 106 technical specifications have been released, aimed at providing the range of acceptable values of chosen indicators. In several cases a more detailed level of measurement specification was defined, delivering a set of sub-technical specification for a single specification. As sample, Figure 1 depicts the elicitation tree for one of the comprehensibility requirements. 
Figure 1: Example of the elicitation process from the requirement category to sub-technical specifications

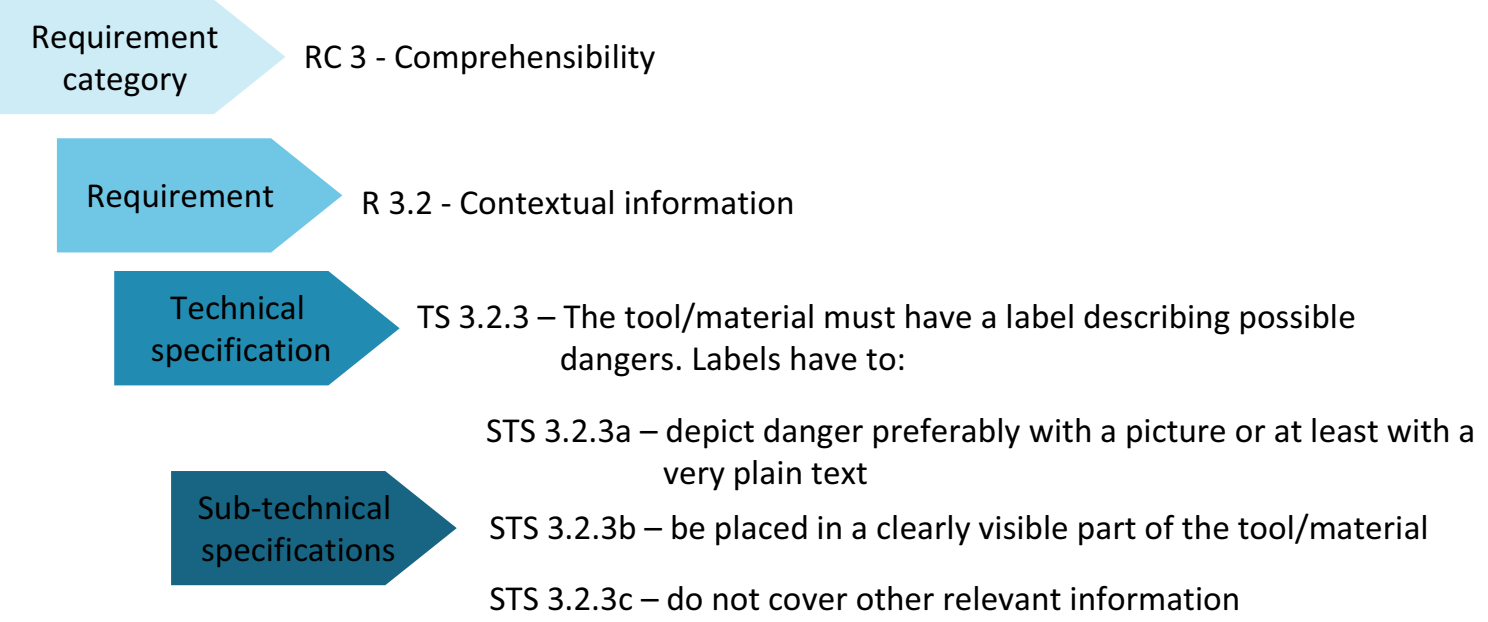

Last step of the methodology formulation consisted of the matching of each tool or material with the set of technical specification applicable, in consideration of object'a specific purposes and tasks.

For what concerns materials, it has to be noticed that technical specifications have been referred to the single object (e.g. block, brick, etc.), loose quantities (e.g. for lime or cement) and packaging (e.g. pallet, sacks, etc), according the relevance of one or more of those aspects to the given specification.

\section{The experimental study}

\subsection{Data gathering and analysis}

The methodology for usability assessment was applied on the field, comparing a selection of 18 bricklayer tools and 8 construction materials. At least three different manufacturer's brand among market leaders for each tool/material were chosen.

The data gathering of quantitative and qualitative indicators of technical specifications has been conducted, referring to information provided by technical sheets, sales literature, information graspable on sight or measurable with simple instruments like a weighing scale or a measuring tape. Usability assessment of selected items was carried out checking the compliance of their features with the requested set of technical specification. Tables 2 and 3 exemplify the data gathering for understanding compliance of 5 square trowels with applicable technical specifications: numbers in the cells express the ratio between the number of complied technical specifications and the total number of applicable technical specifications for each requirement.

Table 2

Compliance of analyzed square trowels with technical indicators of usability requirement categories RC 1 , RC 2 and RC 3 .

\begin{tabular}{|c|c|c|c|c|c|c|c|c|c|}
\hline \multirow{2}{*}{ Product n } & \multicolumn{3}{|c|}{ RC 1 - Comfortable use } & \multicolumn{3}{|c|}{ RC 2 - Maintainability } & \multicolumn{3}{|c|}{ RC 3 - Comprehensibility } \\
\hline & R 1.1 & R 1.2 & R 1.2 & R 2.1 & R 2.2 & R 2.3 & R 2.2 & R 3.1 & R 3.2 \\
\hline 1 & $8 / 8$ & $5 / 5$ & $\mathrm{~N} / \mathrm{A}^{*}$ & $3 / 3$ & $1 / 1$ & $1 / 1$ & $\mathrm{~N} / \mathrm{A}$ & $2 / 2$ & $0 / 1$ \\
\hline 2 & $8 / 8$ & $5 / 5$ & N/A & $2 / 3$ & $1 / 1$ & $1 / 1$ & N/A & $2 / 2$ & $1 / 1$ \\
\hline 3 & $7 / 8$ & $5 / 5$ & N/A & $3 / 3$ & $1 / 1$ & $1 / 1$ & N/A & $2 / 2$ & $0 / 1$ \\
\hline 4 & $7 / 8$ & $5 / 5$ & N/A & $2 / 3$ & $1 / 1$ & $1 / 1$ & N/A & $2 / 2$ & $1 / 1$ \\
\hline 5 & $7 / 8$ & $5 / 5$ & N/A & $2 / 3$ & $1 / 1$ & $1 / 1$ & N/A & $2 / 2$ & $0 / 1$ \\
\hline
\end{tabular}

*N/A: Not Available data 
Table 3

Compliance of analyzed square trowels with technical indicators of usability requirement categories RC 4 and RC 5 .

\begin{tabular}{|c|c|c|c|c|c|c|c|c|c|c|c|}
\hline \multirow{2}{*}{ Product n } & \multicolumn{6}{|c|}{ RC 4 - Injury protection } & \multicolumn{5}{|c|}{ RC 5 - Health protection } \\
\hline & R 4.1 & R 4.2 & R 4.3 & R 4.4 & R 4.5 & R 4.6 & R 5.1 & R 5.2 & R 5.3 & R 5.4 & R 5.5 \\
\hline 1 & $1 / 1$ & $1 / 1$ & $1 / 1$ & $3 / 3$ & N/A* & N/A & $3 / 3$ & $2 / 2$ & N/A & $\mathrm{N} / \mathrm{A}$ & N/A \\
\hline 2 & $1 / 1$ & $1 / 1$ & $1 / 1$ & $3 / 3$ & N/A & N/A & $3 / 3$ & $2 / 2$ & N/A & $\mathrm{N} / \mathrm{A}$ & N/A \\
\hline 3 & $1 / 1$ & $1 / 1$ & $1 / 1$ & $3 / 3$ & N/A & N/A & $3 / 3$ & $2 / 2$ & N/A & $\mathrm{N} / \mathrm{A}$ & N/A \\
\hline 4 & $1 / 1$ & $1 / 1$ & $1 / 1$ & $2 / 3$ & N/A & N/A & $1 / 3$ & $2 / 2$ & N/A & $\mathrm{N} / \mathrm{A}$ & N/A \\
\hline 5 & $1 / 1$ & $1 / 1$ & $1 / 1$ & $2 / 3$ & $\mathrm{~N} / \mathrm{A}$ & N/A & $1 / 3$ & $2 / 2$ & $\mathrm{~N} / \mathrm{A}$ & $\mathrm{N} / \mathrm{A}$ & N/A \\
\hline
\end{tabular}

After having completed tables with gathered data, results were summarized in charts showing percentages of applicable usability technical specifications complied by analyzed tools. A sample of this kind of result is given by Figure 2 .

Figure 2: Summary results of square trowels usability assessment.

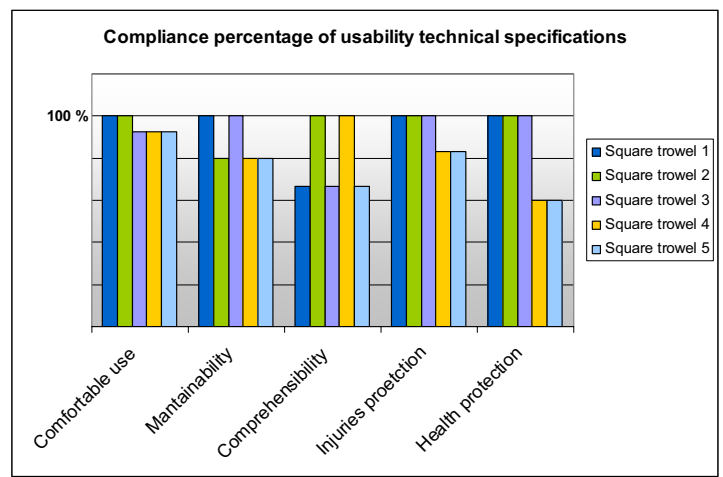

\subsection{Result of the study}

An initial finding concerns technical information provided by the producers of the selected masonry tools and materials, independently on differences among brands and market targets, with a general deficiency of useful data for usability requirements assessment (N/A cells in Tables 2 and 3). As consequence, usability test has provided more accurate results for qualitative technical specifications crosschecking than for quantitative ones. Usability assessment study evidences that selected hand-held construction tools and materials provide inappropriate grips in relation to a lot of characteristics, (i.e. shape, dimension, visibility, easiness to recognize handle points, handling stability, slipperiness resistance, pinch force, weights, easiness to open and to empty). On these basis two outputs have been achieved: a) a guide for usability evaluation allowing the employers to select and buy hand-held tools, materials and packaging best fitting characteristics of users and construction context;

b) specific guidelines to re-design ergonomic construction hand-held tools, materials and packaging.

\section{Discussion}

Wide margins for design improvement exist, considering the gap between the expected usability performances and the actual ones provided by investigated products. A more comprehensive approach to ergonomics of construction materials appears to be useful. Promising research scenarios emerge considering the multiple features of tools and materials which actually affect ergonomic working conditions of bricklayers and their assistants. This perspective would be a key success factor in promoting safety strategies in constructions.

\section{References}

[1] A., Mital and A. Kilbom, A., Design selection of and use of hand tools to alleviate trauma of the Upper extremities", International Journal of Industrial Ergonomics, 10 (1992) pp. 7-21

[2] H. Strasser, B. Wang and Hoffmannt A., "Electromyographic and subjective evaluation of hand tools: The example of masons' trowels", International Journal of Industrial Ergonomics 18 (1996) pp. 91-106

[3] P. Vink, M. Miedema, E. Koningsveld and H. van der Molen "Physical Effects of New Devices for Bricklayers" International journal of occupational safety and ergonomics, Vol. 8 No.1 (2002) pp. 71-82

[4] K. A. Kaminskas "The prevention of trauma by ergonomic equipment in the construction industry", Safety science monitor Vol.7 No.1 (2003) pp. 1-9

[5] P. Spielholz, S. Bao and N. Howard, "A Practical Method for Ergonomic and Usability Evaluation of Hand Tools: A Comparison of Three Random Orbital Sander Configurations", 
Applied Occupational and Environmental Hygiene, Vol. 16 No.11 (2001) pp. 1043-1048

[6] J. A. Hess, L. Kincl, T. Amasay and P.. Wolfe, "Ergonomic evaluation of masons laying concrete masonry units and autoclaved aerated concrete", Applied Ergonomics, 41 (2010) pp. 477-483

[7] P. D. Bust, A. G. F. Gibb and R A Haslam "Manual handling of highway kerbs-focus group findings", Applied Ergonomics 36 (2005) pp. 417-425

[8] Das B, Jongkol and P Ngui S "Snap-on-handles for a nonpowered hacksaw: An ergonomics evaluation, redesign and testing", Ergonomics Vol 48 No.1, (2005) pp.78-97

[9] European Agency for Safety and Health at Work "Workrelated musculoskeletal disorders: prevention report", Office for Official Publications of the European Communities, Luxembourg (2008) http://osha.europa.eu/en/publications/reports/ en TE8107132ENC.pdf [accessed on 14/09/2009]

[10]E. Attaianese, G. Duca, N. Coppola, G. De Margheriti, R. Pascale and V. Troisi, "Assessment of ergonomic quality of hand-held materials and packaging in constructions". In Proceedings TG59 \& W112 - Special Track 18th CIB World Building Congress, CIB Publication 359 (2010), pp. 32-43
[11]H. Strasser and H.-J. Bullinger, "A systematic Approach for the analysis and ergonomic design of hand-held tools and control actuators, in H. Strasser (Ed.) "Assessment of the ergonomic quality of hand-held tools and computer input devices, IOS Press, Lancaster UK, 2007, pp. 1-22

[12]B. Das, Ergonomic evaluation, design and testing of hand tools, in in H. Strasser (Ed.) "Assessment of the ergonomic quality of hand-held tools and computer input devices, IOS Press, Lancaster UK, 2007, pp. 23-39

[13]P Entzel, J. Albers and L. Welch "Best practices for preventing musculoskeletal disorders in masonry: Stakeholder perspectives", Applied Ergonomics, 38 (2007) pp. 557-566

\section{Endnotes}

\footnotetext{
${ }^{\mathrm{i}}$ The EdilUsabile project was carried out in 2009 by dr. Nunzia Coppola, dr. Gabriella De Margheriti and dr. Gabriella Duca, project manager: dr. Erminia Attaianese.

Editorial note for Italian readership: paragraphs 1 and 2 can be attributed to G.D, whilst paragraphs 3 and 4 can be attributed to
} E.A. 